\title{
TEOLOGI KRITIS DI MASA TEROR: STRATEGI PENDIDIKAN TEOLOGI TERORIS
}

\author{
Oleb: Agus Iswanto*
}

\section{Abstract}

This article tries to discus about possibility of theology reconstruction (religious comprehension) in its relation with terrorism action in the name of religion in Islamic education practice. The first, the writer discuses about meanings of theology and terrorism, which are key concepts in this study. Then to investigate the roots. of terrorism in the name of God through religion fundamentalism concept with jibad whose mascot whose rots is political problem. According to the writer, this problem needs the new formula of theology in Islamic education practice. This theology is critical theology inspired by the Islamic universal good norms (The Qur'an and Sunnab). This theology always criticizes comprebension of religious wbich is loaded by political self interest of certain group caused conflict.

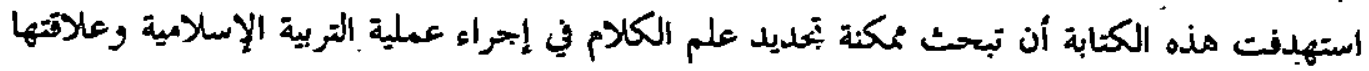

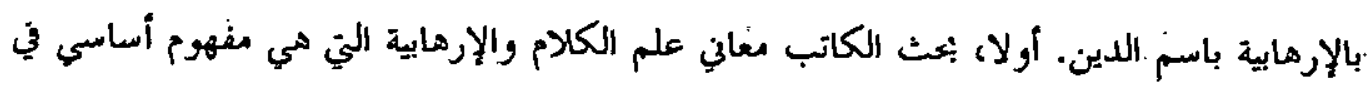
هذ البحث، ثم يبحث أصول الإرهابية باسم الدين في الإسلام بوسيلة مفاهم أصول الدين وهو

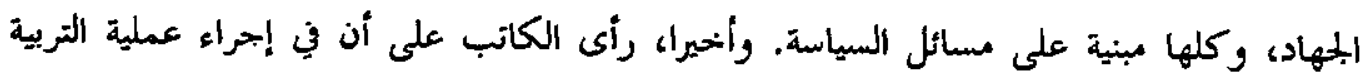

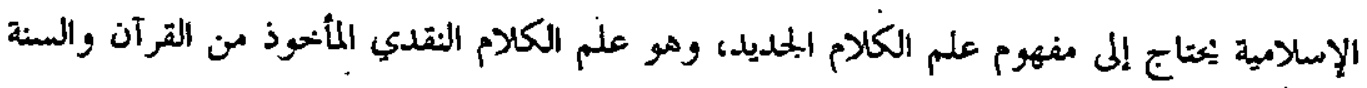
حيث ينتقد مذا العلم فهم الدين الذي يلتبسه الإبتاه السياسي.

Keywords: teologi, terorisme dan pendidikan Islam.

* Penulis adalah mahasiswa konsentrasi Islamic Research Program Pascasarjana (S-2) MSI Universitas Islam Indonesia (UII) Yogyakarta. 


\section{A. Pendabuluan}

Pembicataan tentang terorisme yang dikaitkan dengan agama (Islam) tampaknya akan menemukan momentumnya jika dibicarakan juga tentang fundamentalisme dalam agama (Islam). Meskipun pernyataan ini terlampau mengklaim bahwa kelompok fundamentalis yang melakukan dan bertanggung jawab terhadap serangkaian aksi-aksi terorisme yang banyak memakan korban. Pada kenyataannya, kelompok atau orang yang melakukan tindakan-tindakan kekerasan tersebut berpaham keagamaan yang sempit, sehingga dikatakan sebagai kaum fundamentalis atau kaum skriptualis yang menafsitkan teks-teks suci secara sempit. ${ }^{1}$

Diskusi tentang hubungan antara fundamentalisme dengan terorisme dan ekstrimisme tampak juga momentumnya ketika dikaitkan dengan serangkaian aksiaksi kekerasan yang, menurut penulis, diawali dengan serangan 11 September 2001 terhadap gedung World Trade Center dan gedung Pentagon di New York Amerika Serikat. Serangan ini diduga dilakukan oleh Osama bin Laden. Dari sini kemudian negara-negara yang merasa terancam dengan sasaran dari fundamentalis Islam seperti Amerika dan sekutunya terus berkampanye untuk melakukan perang melawan teroris dengan jargon war againts terrorism. Dengan kampanye ini, bukan menyurutkan semangat "jihad" kaum fundamentalis Islam, tetapi semakin mendorong maraknya aksi-aksi kekerasan dalam bentuk serangkaian bom-bom bunuh diri.

Oleh karena itu, perlu suatu gerakan yang menandingi gerakan terorisme ini. Jika getakan teroris yang didasarkan Islam mengklaim bahwa bom bunuh diri merupakan bagian dari "jihad" membela agama, maka ini adalah doktrin yang begitu saja diterima. Doktrin ini begitu kuat sehingga dapat meyakinkan bahwa mati dengan aksi bom bunuh diri menjadi jaminan masuk surga, karena telah melakukan jihad memetangi musuh Tuhan. Kuatnya doktrin ini tidak dapat hanya dihancurkan atau dihilangkan dengan tindakan-tindakan hukum atau tindakan militer. Tindakan tersebut penting dilakukan, tetapi yang lebih penting bagaimana memberikan pemahaman sejak dini tentang doktrin agama yang lebih damai dan terbuka.

Tulisan ini mencoba mendiskusikan bagaimana pendidikan Islam, khususnya pendidikan tentang teologi yang merupakan ruh dalam pendidikan Islam berperan memberikan pemahaman keagamaan yang inklusif dan terbuka tetapi tetap memegang teguh doktrin-doktrin pokok keimanan. Kendati permasalahan rumusan teologi baru dalam pendidikan Islam tetkait dengan isu terorisme menjadi pokok pembicaraan

${ }^{1}$ Ini merupakan cara pandang Amerika dan sekutu-sekutunya yang menganggap dan memahami bahwa fundamentalisme Islam identik dengan bagian terorisme dan ekstrimisme. Untuk sementara, kategori ini yang dipakai oleh sebagian pengamat masalah fundamentalisme Islam. Lihat Syafiq Hasyim (2002), "Fundamentalisme Islam: Perebutan dan Pergeseran Nakna" dalam Taswirul Afkar Jumal Refleksi Pemikiran Keagamaant dan Kebuddyadm, Jakarta: Lembaga Kajian dan Pengembangan Sumber Daya Manusia NU, p. 5. 
dalam tulisan ini, tetapi pertanyaan-pertanyaan: adakah kaitannya fundamentalisme Islam dengan terorisme?; apakah fundamentalisme itu hanya ada dalam Islam?; bagaiamana sebenannya struktur fundamentalisme dibangun dalam Islam?; dan apakah fundamentalisme itu selamanya didasari oleh kepentingan agama? juga menjadi pembahasan dalam tulisan ini.

\section{B. Teologi: Berbagai Pemaknaan}

Istilah teologi tidak tercatat dalam kamus studi Islam klasik. Para ulama klasik dan juga kebanyakan umat Islam, lebih senang dan sering menggunakan kata ilmu tauhid, aqidah (keyakinan), usbuluddin (dasar-dasar agama), atau mungkin yang lebih dikenal oleh kalangan sarjana dalam studi Islam adalah istilah ilmu kalam. Istilah teologi memang muncul dalam wacana istilah keagamaan Kristen yang berarti ilmu tentang Tuhan (theos berarti Tuhan dan logos berarti ilmu). Lantaran demikian istilah ini kurang disenangi oleh kebanyakan muslim dan bahkan antipati serta menimbulkan pandangan-pandangan sinis lainnya terhadap istilah ini.

Menurut Amin Abdullah, istilah teologi itu dapat digunakan untuk mendefinisikan pandangan keagamaan yang terinspirasikan oleh ajaran al-Qur'an dan Sunnah, baik dari sisi normatif maupun historis terhadap fenomena kehidupan. ${ }^{2}$ Menurut hemat penulis, definisi ini dapat digunakan tidak saja untuk menyebut istilah pandangan keagamaan yang terinspirasikan oleh al-Qur'an dan Sunnah, tetapi juga yang terinspirasikan oleh dasar-dasar pokok ajaran dalam setiap agama, sehingga istilah teologi dapat lebih luas dan bisa digunakan untuk agama yang lain. Sampai di sini mungkin akan sedikit jelas, tetapi kenyataannya istilah yang dibuat ini menghilangkan makna asli dari kata teologi itu sendiri. Secara eksplisit, hal ini seakanakan menafikan kata teologi dalam makna "ilmu tentang Tuhan," tetapi secara implisit, menurut hemat penulis, definisi di atas tampak memberikan ruang bagi pemahaman ilmu tentang problem ketuhanan. Sebab, dengan ilmu initah dimensi historisitas "ketuhanan" yang mengambil bentuk institusi keagamaan tampak jelas. Dengan demikian, pemahaman keagamaan akan sangat terkait dengan "pengalamanpengalaman duniawi" dalam dimensi sosialnya. Pada titik ini, aliran-alitan teologi (ilmu kalam) yang muncul secara luas dapat dipahami sebagaimana yang akan diurai dalam pembahasan berikut.

\section{Terorisme: Berbagai Pemaknaan}

Bagi penulis, adanya fakta sekarang ini yang menunjukan bahwa seakan-akan terorisme didasatkan atau dilandasai oleh doktrin-doktrin agama, tidak serta merta dapat ditarik kesimpulan secara umum bahwa sebab utama terorisme adalah doktrin

${ }^{2}$ M. Amin Abdullah (2000), Dinamika Islam Kultural Pemetaan atas IWacana Keislaman Kontemporer, Bandung: Mizan, p. 94. 
agama. Doktrin agama (teologi) merupakan bagian dari hal-hal yang menyebabkan terorisme. ${ }^{3}$ Istilah terorisme dapat dikatakan rumit. Istilah ini bukan hanya sekedar istilah biasa, melainkan telah menjadi wacana baru yang ramai dibicarakan dan mempunyai implikasi yang besar bagi tatanan politik global. Terorisme bukan sekadar diskurus, akan tetapi merupakan fakta dari sebuah gerakan global yang hinggap di mana pun dan kapan pun. Kemunculan terotisme sebagai sebuah wacana sangat erat kaitannya dengan keinginan dari pihak yang mengkonstruksinya, kekuasaan yang mengitarinya, disiplin yang mengaturnya juga rezitn yang berkuasa. ${ }^{4}$

Kata "teroris" (pelaku) dan terorisme" (aksi) berasal dari kata latin "terrere" yang berarti membuat gemetat atau menggetarkan. Kata teror juga dapat memunculkan kengerian. Istilah terorisme untuk pertama kalinya dibahas dalam European Convention on the Suppression of Terrorism (ECST) di Eropa pada tahun 1977 yang berarti crimes againts state, yang kemudian terjadi perubahan paradigma menajadi crimes againts bumanity, yang meliputi tindak pidana untuk menciptakan suatu keadaan yang mengakibatkan individu, golongan, dan masyarakat umum ada dalam suasana teror. Konvensi perserikatan bangsa-bangsa (PBB) pada tahun 1937 mendefinisikan terorisme sebagai segala bentuk tindak kejahatan yang ditujukan langsung kepada negara dengan maskud menciptakan suasana teror terhadap orangorang tertentu atau kelompok orang atau masyarakat luas. ${ }^{5}$

Sejauh ini, definisi yang dapat diterima dan lebih dimengerti adalah definisi terorisme yang dibuat oleh penguasa dan kekuasaan, yakni sebuah paham yang menggunakan kekerasaan yang dilakukan oleh sekelompok organisasi atau individu yang tujuannya untuk melakukan intimidasi dan memaksa pemerintah untuk mempromosikan kepentingan-kepentingan politik, agama, dan ideologi tertentu. ${ }^{6}$ Ini tentu merupakan hegemonik dari pihak yang mungkin merasa dirugikan dengan tindakan teroris itu dan pada saat yang sama pihak yang merasa dirugikan ini mempunyai kekuasaan dan kekuatan. ${ }^{7}$

Ali A Mazrui membedakan dua bentuk terorisme, pertama adalah yang disebut dengan herrofic terrorism. Tetorisme jenis ini adalah jenis teroris yang mengerikan dan merupakan kejahatan terhadap kemanusian dengan cara membunuh orang tidak berdosa dan tidak bersenjata serta menggunakan alat-alat yang tidak lazim digunakan

${ }^{3}$ Juhaya S. Praja (2004), Islam Globalisasi dan Kontra Terorisme: Islam Pasca Tragedi 911, Bandung: Kaki Langit, p. 31.

${ }^{4}$ Untuk keterangan lebih lanjut tentang relasi pengetahuan dengan kekuasaan, baca Foucault, Nichael (1983), Beyond Strutturalism and Hermeneutics, Chicago: University of Chicago Press.

${ }^{5}$ Lihat Harian Kompas, 29 Oktober 2002.

- Juhaya S. Praja, op. cit., p. 30.

${ }^{7}$ Ini dapat lihat dengan memperhatikan peristiwa-peristiwa sejak dibornnya WTC dan gedung Pentagon Amerika. Wacana terorisme semakin banyak dibicarakan yang menggunakan pernyataan perang dengan terorisme. 
dalam suatu perang konvensional. Ia mengkategorikan peristiwa 11 September dalam teroris jenis ini. Kedua adalah beroic terrorism. Terorisme jenis ini merupakan terorisme patriotik dan kepahlawanan. Menurutnya, bom bunuh diri pemuda Palestina atas pendudukan Israel masuk dalam ketegori terorisme ini. ${ }^{8}$

Terorisme dapat diartikulasikan dalam tiga bentuk. Pertama, terorisme yang bersifat personal. Terorisme perorangan, biasanya dilakukan dalam pengeboman bus, pengeboman mal-mal, atau tempat wisata. Kedua, terorisme kolektif, yaitu terosisme yang dilakukan secara berencana dan dilembagakan dalam sebuah jaringan yang rapi. Sasatan terotisme jenis ini adalah simbol-simbol kekuasaan dan pusat-pusat perekonomian. Al-Qaeda dapat dimasukan dalam kategori ini. Ketiga, tetorisme negara. Terorisme ini adalah tindakan teror yang dilakukan oleh negara. ${ }^{9}$ Untuk dua jenis terorisme yang pertama di atas tampak saling terkait dan sulit untuk dibedakan secara ekstrim. Terkadang terorisme personal juga bagian dati terorisme kolektif dan begitu juga sebaliknya. Berbagai peristiwa yang dapat disebut antara lain; pengeboman bus turis asing di Kairo, penembakan para turis di Luxor, Mesir, pengeboman Kedubes AS di Kenya ${ }^{10}$ dan insiden yang serupa. Khusus di Indonesia peristiwa yang masih dekat dalam ingatan adalah tragedi bom Bali I dan II. Tindakan ini merupakan bentuk-bentuk terorisme yang bisa disebut sebagai tindakan personal sekaligus tindakan kolektif, yang tujuannya sama, yakni merusak dan menimbulkan jatuhnya korban.

Terorisme selalu identik dengan teror, kekerasan, ekstrimisitas, dan intimidasi, baik itu dalam bentuk herrofic terrorism maupun beroic terrorism. Keduanya merupakan bentuk kekerasan. Para pelakunya disebut teroris. Oleh karena itu, tindakan terorisme seringkali kali menimbulkan akibat yang negatif bagi kemanusian. Terorisme kerap menjatuhkan korban kemanusian dalam jumlah yang banyak. Gejala-gejala terorisme sebagai "proses teror" dapat dikenali dengan tiga unsur: 1) tindakan atau ancaman kekerasan; 2) reaksi emosional terhadap ketakutan yang amat sangat dari pihak yang diteror (korban atau calon korban); dan 3) dampak sosial yang muncul mengikuti kekerasan atau ancaman tersebut."

Terorisme dapat muncul karena ajaran agama atau karena motivasi agama. ${ }^{12}$ Sampai di sini, muncul pertanyaan adakah korelasi yang fungsional antara Islam dengan Tetorisme? Tanggapan beragam pun muncul terkait dengan stigma Islam sebagai agama teroris. ${ }^{13}$ Akar-akar terorisme yang dilandasi dengan doktrin agama

${ }^{8}$ Juhaya S. Praja, op. cit., p. 30.

${ }_{9}$ Zuhairi Misrawi (2002), Islam dan Terorisme, http://wwwislamlib.com, p. 1.

${ }^{10}$ Ibid., pp. 1-2.

It Azyumardi Azra (1996), Pergolakan Poltik Islam: Dari Fundamentalisme, Modernisme Hingga PostModernisme, Jakarta: Paramadina, p. 145.

12 Juhaya S. Praja, op. cit., p. 31.

${ }^{13}$ Stigma-inimemang agak berlebihan tetapi untuk sementara dapat dibenarkan apabila melihat 
dalam Islam tampaknya mendapat tempat dalam konteks pembicaraan tadikalisme dan fundamentalisme agama. ${ }^{14}$ Oleh karenanya pembicaran radikalisme dan fundamentalistne Islam yang dikaitkan dengan terorisme akan mendapat tempat pula jika dikaitkan dengan konsep jibad yang sering digunakan sebagai pembenaran terhadap tindak kekerasan yang harus dilakukan. Jihad ini tentu saja mempunyai landasan teologis yang cukup berpengaruh bagi gerakan radikalisme dan fundamentalisme Islam .

\section{Jibad, Fundamentalisme dan Radikalisme Islam: Dari Teologis Hingga Politis}

Secara terminologis, fundamentalisme Islam hingga kini masih menjadi perdebatan baik di kalangan Islam sendiri maupun para Islamis (orientalis): Salah satu hal yang dipetdebatkan adalah masalah penggunaan istilah fundamentalisme itu sendiri dalam konteks Islam. ${ }^{15}$ Istilah fundamentalisme secara etimologi betasal dari kata fundamen yang berarti "dasar". Sedangkan secara terminologi, fundamentalisme betarti "aliran pemikiran keagamaan yang cenderung menafsirkan teks-teks keagamaan secara rigid (kaku) dan literalis (tekstual)". ${ }^{16}$ Habermas menyebutkan bahwa istilah fundamentalisme mempunyai makna pejoratif. Istilah ini mencirikan suatu mental yang khas, suatu sikap "kepala batu" yang menekankan didesaknya secara politis keyakinan-keyakinan serta alasan-alasan mereka sendiri meskipun tidak rasional. ${ }^{17}$ Bagi Bassam Tibi, makna yang pejoratif bagi fundamentalisme ini dipahami jika fundamentalisme dapat diartikan sebagai gejala ideologi yang muncul sebagai respon problem-problem globalisasi, fragmentasi dan benturan peradaban. Istilah ini menimbulkan kesan tertentu misalnya ekstrimisme, fanatisme atau bahkan terorisme dalam mewujudkan dan mempertahankan keyakinan keagamaannnya. ${ }^{18}$

Terdapat sejumlah ptinsip yang sering kali dilekatkan bagi istilah fundamentalisme Islam ini, di antaranya adalah: pertama, memberi penekanan pada

fakta yang terjadi. Aksi-aksi atau peristiwa-peristiwa bom bunuh diti yang makin hari makin sering didengat tampak selalu para pelakunya melandaskan pada doktrin-doktrin suci agama (Islam).

${ }^{1+}$ Pandangan seperti ini bukan berarti hegemoni terhadap sebuah aliran keberagamaan yang tidak mapan di masyarakat, tetapi ini lebih dati sebuah fakta yang ada. Kajian tentang tindakan "teror" terhadap kelompok keagamaan lain tampak perlu dilakukan sebagai balancing bagi kajian-kajian tentang fundamentalisme Islam dan terorisme, termasuk kajian iri.

${ }_{15}$ Terminologi atau istilah fundamentalisme agama justru muncul pertama kali di kalangan Kristen.

${ }^{16}$ Mahmud Amin AI-'Alim (1993), "al-Fikr al-'Araby al-Mu'âshir baina al-Ushûliyîn wa al'Almâṇiyah" dalam al-Usbûlijah al-Islamiyah, Kairo: Qadhâyâ Fikriyah li an-Nasyr wa at-Tauzi', p. 10.

17 Giovana Borradori (2005), Filsafat dalam Masa Teror, Jakarta: PT. Kompas Media Nusantara, p. 46.

${ }^{18}$ Abdurrahman Kasdi (2002), "Fundamentalisme Islam Timur Tengah" dalam Tashwirnl Afkar, ibid., p. 20. 
interpretasi literal terhadap teks-teks suci agama. Kedua, setiap gerakan fundamentalis selalu dapat dihubungkan dengan fanatisme, ekslusifisme, intoletan, tadikalisme, dan militanisme. Ketiga, menolak isme-isme modern yang tidak sesuai dengan kitab suci. Keempat, adanya monopoli kebenaran atas tafsir agama. Kelima, penolakan terhadap plưralisme dan relativisme.$^{19}$

Jika dilihat dari beberapa kategori di atas, maka tampak bahwa fenomena fundamentalisme Islam memiliki akar politis yang sedari kemunculannya memang metupakan masalah politis dan juga, pada tahap selanjutnya menjadi masalah teologis. Tetapi tampaknya sulit untuk mengurai mana yang merupakan problem teologis dan mana yang merupakan problem politis. ${ }^{20}$ Kesulitan ini disebabkan oleh saling terkait kelindannya antara kepentingan politis dengan argumen teologis yang dijadikan dasar. Inilah problem yang utama yang harus segera dipecahkan, yakni pernisahan mana wilayah teologis murni dan mana wilayah politis sebelum akhirnya melakukan rekonstruksi tethadap konstruksi teologi Islam.

Dalam wacana teologi Islam (ilmu kalam), awal mula konflik teologis bermula dari sebuah peristiwa yang disebut dengan al-fitnab al-kubra. Dari peristiwa ini kemudian muncul berbagai aliran-alitan dalam teologi Islam, yang tentu saja sudah ditunggangi oleh kepentingan-kepentingan lain selain pure teologi. Dalam kaitannya dengan fundamentalisme Islam, aliran atau kaum Khawarij sering disebut-sebut sebagai prototype aliran tersebut. Gerakan Khawarij dapat disebut sebagai gerakan fundamentalis Islam klasik. Gerakan Khawarij yang muncul dari pertikaian Khalifah 'Ali bin Abi Thalib dengan Mu'awiyah bin Abi Sufyan, terkenal dengan prinsipprinsip yang radikal dan ekstrim. Bagi mereka tidak ada hukum selain hukum Allah (la bukm illa Allab). Diktum ini muncul ketika kelompok Ali menyetujui untuk melakukan arbitrase dengan kelompok Mu'awiyah, yang menurut kaum Khawarij bertentangan dengan ketentuan Tuhan. Katenanya pihak-pihak yang melakukan arbitrase ini adalah kafir. Permasalahan kafir, dengan demikian bukan lagi permasalahan politik tetapi sudah menjadi masalah teologi.

Selanjutnya, getakan fundamentalis Islam dapat dibagi menjadi beberapa periode; getakan fundamentalis pra-modern dan gerakan fundamentalis modern. Gerakan fundamentalis Islam pra-modern, akar-akamya telah tampak, sebagaimana telah dijelaskan di atas pada kaum Khawatij. Selain itu juga pada gerakan Wahabiyah, yang merupakan sebuah gerakan yang dipimpin oleh Muhammad ibn Abdul Wahab

19 Martin E. Marty (1992), "What is Fundamentalism? Theological Percpective" dalam Hans Kung dan Jurgen Moltmann (eds); Fundamentalism as a Ecumanical Challenge, London, pp. 3-13. Lihat juga tulisan Azyumardi Azra, op. cit., pp. 109-110:

${ }^{20}$ Harun Nasution berpendapat bahwa persoalan politik adalah awal mula munculnya persoalanpetsoalan teologi. Lihat Harun Nasution (1986), Islam Ditinjau dari Berbagai Aspeknya, jilid II, Jakarta: Bulan Bintang, p. 31. 
(1703-92). Gerakan ini muncul karena banyak dipengaruhi oleh gagasan-gagasan pembaruan Ibn Taimiyah. Ibn Abdul Wahab mampu membawa gerakan ini mencapai titik ekstrim, yakni fundamentalisme Islam radikal. Gerakan ini mengajatkan jihad kepada seluruh kaum Muslim untuk menghancurkan segala hal yang dipandangnya telah menyimpang dari Islam, seperti apa yang disebut dengan takbayul, kburafat, dan bid'ab. Fundamentalisme Islam, baik yang secara langsung ataupun tidak langsung dipengaruhi oleh gerakan Wahabi ini, selanjutnya banyak betmunculan diberbagai daerah Muslim. ${ }^{21}$

Pada tahap selanjutnya, di era modern, juga muncul getakan fundamentalisme Islam yang akar-akamya dapat dilacak pada tokoh-tokoh Hasan al-Bana, Sayyid Quthb, dan al-Mawdudi. Ketiganya ini bertemu pada satu wadah organisasi atau getakan Ikbwanul Muslimin. Al-Bana memfokuskan pada usaha bagaimana menunujukan bahwa Islam sebagai ideologi yang total dan komperensif. Sedangkan Quthb terkenal dengan istilahnya "jabiliyab modern". Jabiliyab modern merupakan situasi, di mana nilai-nilai fundamental yang diturunkan Tuhan kepada manusia diganti dengan nilai-nilai palsu yang berdasarkan hawa nafsu dunia (modernitas). Oleh karena itu, umat Islam harus melakukan perubahan yang fundamental dan radikal dengan cara melakukan serangan jihad secara sistematis terhadap bentuk modernitas. ${ }^{22}$ Dengan konsep jihad, atau perang suci, maka getakan fundamentalis menggariskan batas-batas perang. Oleh karena itu, dapat dikatakan bahwa jihad digunakan oleh gerakan fundamentalis Islam sebagai spirit perjungannva. Jihad merupakan masalah teologis dan doktrin, ataukah masalah politik yang dicarikan dasarnya dalam agama, masih menjadi pertanyaan tersendiri.

Pada kenyataannya, agama apapun tidak ada yang mendukung terhadap segala aksi kekerasan. Jika dilihat dari akar katanya, jihad bermakna "berusaha dengan sungguh". Di dalam al-Qur'an, kata ini banyak digunakan dalam konteks usaha untuk memerangi segala sesuatu yang mengancam Islam. Karenanya, jihad sering dijadikan sebagai legitimasi perang suci (boly war) atas nama agama. ${ }^{23} \mathrm{Di}$ samping kata jihad, dalam al-Qur'an terdapat kata lain yang juga bermakna "perang" seperti al-qital, yang artinya membunuh atau bertempur. Kata ini biasa dipakai untuk halhal yang menyangkut fisik dan militeristik. ${ }^{24}$ Dalam al-Qur'an, ketiga makna tersebut tercakup dalam kata jihad. Sehingga jihad dapat berarti dua dimensi; lahir yang betkaitan dengan fisik, dan batin yang berkaitan dengan makna spiritual. Secata historis, jihad lebih berkaitan dengan aktifitas politik daripada dakwah, yang

${ }^{21}$ Azyumardi Azra, op. cit., pp. 110-112.

${ }_{22}$ Juhaya S. Praja, op. cit., p. 120.

${ }^{23}$ Rumadi (2002), "Jihad: Mengapa Jadi Hantu Islam?" dalam Tashwirul Afkar, op. cit., p. 60.

${ }^{24}$ Lihat al-Qur'an 2: 190, 216, 217, 244; 4: 74-76; 8: 39, 65; 9:5-6,12-16, 29, 123; 22: 39-41; 47:4, 20: $48: 17$. 
seharusnya jihad lebih dimaknai sebagai spirit teologis dalam dakwah.

Sampai disini, dapat dimengerti bahwa doktrin jihad sering kali digunakan sebagai legitimete tindakan-tindakan kekerasan yang dilakukan oleh kaum fundamentalis Islam untuk mencapai tujuan-tujuannya, tidak terkecuali dengan teror. Akibatnya, Islam yang mempunyai konsep jihad dianggap sebagai agama yang betpotensi metnunculkan teror.

Dengan demikian, akar-akar teroristik dalam Islam dapat dengan mudah dilihat dalam wajah gerakan fundamentalis Islam yang menjadikan jihad sebagai maskotnya dan gerakan Khawarij adalah prototype gerakan fundamentalis Islam. Paling tidak ada tiga akar teologis dalam pemikitan tetoris. Ketiga akar ini juga berkaitkan dengan getakan fundamentalis Islam. Pertama, ada semacam keinginan untuk menegakan agama Tuhan secata paksa. Kedua, adanya anggapan, bahwa pandangan metekalah yang paling benar. Ketiga, adanya harapan akan kemartiran (syubada). ${ }^{25}$

\section{E. Strategi Pendidikan Teologi Teroris: Pendidikan Teologi Kritis}

Menurut penulis, teologi-teologi yang berkembang dan diajarkan dalam praktik pendidikan Islam sekarang ini adalah wujud nyata, meminjam istilah Muhammad Arkoun, dari apa yang disebut taqdis al-afkar al-diniyab (pensakralan pemikiran keagamaan). Sehingga pemikiran-pemikiran atau ajaran yang diajarkan sampai di hadapan santri, siswa, dan mahasiswa adalah seperangkat doktrin-doktrin yang bersifat ekslusif, subyektif, dan apologetis. Akibatnya, pendidikan-pendidikan yang hanya "melestarikan" doktrin-doktrin itu pada akhirnya hanya akan memunculkan aliran-aliran dan sekte-sekte yang terkotak-kotak dan ekslusif.

Kenyataan ini memang dimaklumi lantaran sifat pemikiran teologis itu mengacu pada agama atau keyakinan tertentu yang memberikan argumen-argumen untuk mempetteguh keyakinannya. Akibatnya teologi ini lebih bersifat subyektif, apologetis, dan lebih menggunakan bahasa pelaku daripada bahasa pengamat. ${ }^{26}$

Oleh karena itu, petlu suatu konstruksi teologi baru yang dilakukan dalam praktik kependidikan Islam. Kontruksi teologi yang baru ini tentunya dalam ptosesnya memerlukan strategi-strategi yang harus disusun agar terwujud kontruksi tersebut. Realitas terorisme yang didasarkan atas fundamentalis Islam merupakan salah satu bentuk pemikiran keagamaan kontempore ${ }^{27}$ meskipun akar-akarnya dapat dilacak di masa klasik. Proses transformasi pemikiran keagamaan itu dilakukan dengan pendidikan. Dengan demikian, pendidikan merupakan "lahan strategis" untuk

${ }^{35}$ Zuhaiti Misrawi (2005), Aksi Terorisme Melawan Agama dan Kemanusiaan, http://www. islamlib.com., p. 3.

${ }^{26}$ Eric J. Sharpe (1986), Comparative Religion of History, London: Duckworth, p. 313.

${ }^{27}$ Hal-ini dikatakan oleh Sayjed Hosein Nasr sebagaimana dikutip oleh M. Amin Abdullah (1996), Studi Agama: Normativitas atau Historisitas?, Yogyakarta: Pustaka Pelajar, p. 29. 
mulai menggarap konstruksi teologi yang baru.

Untuk itu, hal pertama yang harus dilakukan adalah merumuskan kembali konsep pendidikan Islam. Pendidikan dalam bahasa Atab adalah tarbiyab, sehingga sering disebut dengan al-tarbiyah al-Islamiyah. Arti sejatinya dari kata tarbiyah adalah pemelihataan, pengarahaan, perbaikan, dan penyempurnaan, atau secara umum tarbiyab berarti pengarahan dan perbaikan. ${ }^{28}$ Dari sini saja, jelas pendidikan bukan betarti pemberian doktrin-doktrin yang eksklusif, tetapi proses pengarahan dan petbaikan untuk menuju manusia yang sempurna (al-insan al-kamil) yang diinspirasikan oleh nilai-nilai yang terkandung dalam al-Qur'an dan Sunnah (Islam).

Pendasaran terhadap al-Qur'an dan Sunnah bukannya tanpa masalah. Masalah muncul ketika dilakukan penafsiran-penafsitan tethadap al-Qur'an dan Sunnah tetsebut. Pada wilayah ini, dimensi "dunyawiyab" dan sosiologis berperan kuat dalam menentukan penafsiran-penafsiran yang tidak terkecuali kepentingan-kepentingan politis telah turut mewarnai perdebatan antara berbagai alitan teologi klasik. Lalu munculah historisitas petnahaman dan pemikitan keagamaan. Tetapi hal itu tidak serta merta menanggalkan nilai-nilai universalistas Islam yang terdapat dalam alQur'an dan Sunnah, yang sejatinya termaktub dalam al-Qur'an sendiri.

Berkenaan dengan hal di atas, strategi yang kedua dapat dilakukan dengan merumuskan dan mendefinisikan teologi dalam rumusan yang baru. Teologi itu penulis sebut dengan teologi di masa kritis dan krisis. ${ }^{29}$ Sifat kritis yang melekat dalam teologi ini seharusnya bukan metupakan sesuatu yang baru, tetapi sesuai dengan kategoti ilmu dalam istilah teologi itu sendiri. Sehingga dimungkinkan untuk menyebut teologi sebagai penalaran kritis tentang Tuhan. ${ }^{30}$ Dengan sifatnya yang ktitis dalam teologi ini dimungkinkan untuk mengaktualkan teologi dalam masa yang penuh krisis seperti krisis motal hingga "krisis terot". Teologi kritis di masa krisis merupakan usaha manusia untuk memahami pengahayatan imannya atau penghayatan agamanya. Ini merupakan suatu penafsiran atas sumber-sumber aslinya dan tradisinya dalam konteks permasalahan masa kini. Dengan demikian teologi di sini merupakan teologi yang bergerak antata dua kutub, yaitu teks dan situasi, masa lampau dan masa kini. Teologi kritis ini juga berarti bahwa teologi sebagai kritik agama yang menyaran pada ungkapan kritik berbagai kecendrungan dalam institusi agama yang menghambat tugas dan panggilan semestinya, yakni menyelamatkan manusia dan kemanusian. ${ }^{31}$ Teologi kritis ini juga dapat bersikap kritis terhadap

${ }^{28}$ Abd. Rahman Abdullah (2001), Aktualisasi Konsep Dasar Pendidikan Islam: Rekonstruksi Pemikiran dalam Tinjawan Filafat Pendidikan Islam, Yogyakarta: UII Press, p. 22.

${ }^{29}$ Istilah ini terinspirasikan dan meminjam dari buku Abudin Nata (2002), Metodologi Studi Islam, Jakarta: Rajawali Press, p. 31 .

${ }^{30}$ Lihat Komaruddin Hidayat (2004), Menafsirkan Kehendak Tuhan, Jakarta: Teraju, p. 189, utamanya bab "Dari Teologi ke Sosiologi".

${ }^{31}$ Bandingkan dengan Abudin Nata, op. cit. 
lingkungannya melalui bantuan ilmu-ilmu sosial, sehingga dapat diketahui faktotfaktot penghambat realisasi keadilan sosial dan emansipasi serta kemanusian. Tampaknya sampai di sini, penulis petlu mengungkapkan apa yang disebut oleh para ahli ushul fiqh dengan maqashid al-syari'ab (tujuan syari'ah). Istilah ini menurut penulis bisa dijabarkan secara luas yang tidak hanya pada masalah-masalah hukum atau $f$ iq $h$, tetapi juga bisa digunakan untuk menyebut substansi teks suci yang merupakan, meminjam istilah Ahmad Baso, "komitmen Tuhan bagi kemaslahatan manusia atau nilai-nilai kebajikan yang universal". ${ }^{32}$ Sehingga teologi ini dapat dirumuskan sebagai pemahaman keagamaan yang berpijak pada nilai-nilai substantif yang terinspirasikan oleh al-Qur'an dan Sunnah.

Dengan rumusan teologi seperti di atas, pendidikan teologi yang diajarkan dan dittansformasikan bukan suatu kumpulan doktrin-doktrin yang partikular dan ekslusif, dimana pada akhirnya akan melanggengkan atau bahkan menambah konflik dan perdebatan antar institusi agama yang masing-masing membela dan mempertahankan agamanya secara ekslusif. Jika demikian, agama yang aturannya membawa rabmat, kedamaian, akan membawa bencana dan konflik.

Rumusan teologi baru dalam praktek kependidikan semacam ini pada akhirnya akan mampu mengembalikan pendidikan pada kbittab-nya sebagai pengarah dan perbaikan pemahaman keagamaan berbasiskan nilai-nilai universal yang substantif dalam al-Qur'an dan Sunnah. Nilai-nilai substantif itu tiada lain adalah kebajikan universal Tuhan untuk kemanusian. Dalam prakteknya nilai-nilai substantif-universal itulah yang diajarkan dalam pendidikan teologi secara kritis dan bukannya secara dogmatis.

\section{F. Penutup.}

Dari uraian dan penjelasan di atas, dapat diarik kesimpulan sebagai berikut; Pertama, permasalahan teologi sering kali menjadi kambing hitam atas tindakan teror yang dilakukan katena paham fundamentalisme dan radikalisme Islam. Akibatnya Islam sering dicap sebagai agama yang menganjurkan kekerasan. Kedua, dalam masa yang penuh teror yang agama sering kali dijadikan dasar, membutuhkan suatu rumusan teologi baru dalam praktik pendidikan Islam, terutama pendidikan teologi. Rumusan teologi yang baru dan perlu dilaksanakan dalam praktek kependidikan tersebut adalah teologi kritis yang berbasiskan realitas dengan diinspirasikan oleh nilai-nilai kebajikan universal Tuhan yang tersirat dalam al-Qur'an dan Sunnah.

${ }^{32}$ Lihat Setyo Hajar Dewantoro, "Islamisasi Ilmu Pengetahuan: Sebuah Tinjauan Kritis" http:// www.fahmina.org. 


\section{DAFTAR PUSTAKA}

Abd. Rahman Abdullah (2001), Aktualisasi Konsep Dasar Pendidikan Islam: Rekonstruksi Pemikiran dalam Tinjauan Filafat Pendidikan Islam, Yogyakarta: UII Ptess.

Abdurrahman Kasdi (2002), "Fundamentalișme Islam Timur Tengah" dalam Tasbuirul Afkar Jurnal Refleksi Pemikiran Keagamaan dan Kebudayaan, Jakarta: Lakpesdam NU.

Abudin Nata (2002), Metodologi Studi Islam, Jakarta: Rajawali Ptess.

Azyumardi Azra (1996), Pergolakan Politik Islam: dari Fundamentalisme, Modernisme Hingga Post-Modernisme, Jakarta: Paramadina.

Borradori, Giovana (2005), Filsafat dalam Masa Teror, Jakarta: PT. Kompas Media Nusantara.

Foucault, Michael (1983), Beyond Structuralism and Hermeneutics, Chicago: Universty of Chicago Press.

Hatun Nasution (1986), Islam Ditinjau dari Berbagai Aspeknya, jilid II, Jakarta: Bulan Bintang.

Juhaya S. Praja (2004), Islam, Globalisasi dan Kontra Terorisme: Islam Pasca Tragedi 911, Bandung: Kaki Langit.

Komaruddin Hidayat (2004), Menafsirkan Kebendak Tuban, Jakatta: Teraju.

Mahmud Amin Al-'Alim (1993), "al-Fikr al-'Araby al-Mu'âshir baina al-Ushûliyîn wa al-Almâniyah" dalam al-Usbâliyah al-Islamiyah, Kairo: Qadhâyâ Fikriyah li an-Nasyr wa at-Tauzi'.

Marty, Martin E. (1992), "What is Fundamentalism? Theological Percpective" dalam Hans Kung dan Jurgen Moltmann (eds), Fundamentalism as a Ecumanical Challenge, London.

M. Amin Abdullah (1996), Studi Agama: Normativitas atau Historisitas?, Yogyakarta: Pustaka Pelajar.

(2000), Dinamika Islam Kultural: Pemetaan atas Wacana Keislaman Kontemporer.

Bandung: Mizan.

Syafiq Hasyim (2002), "Fundamentalisme Islam: Perebutan dan Pergeseran Makna" dalam Taswirul Afkar Jurnal Refleksi Pemikiran Keagamaan dan Kebudayaan, Jakarta:

Lembaga Kajian dan Pengembangan Sumber Daya Manusia NU.

Rumadi (2002), "Jihad: Mengapa Jadi Hantu Islam?" dalam Tasbwirul Afkar Jurnal

Refleksi Pemikiran Keagamaan dan Kebudayaan; Jakarta: Lembaga Kajian dan

Pengembangan Sumber Daya Manusia NU.

Sharpe, Eric J. (1986), Comparative Religion of History, London: Duckworth. 